\title{
Abundance of Butterflies at Hudson Bay Junction
}

\author{
By DONALD HOOPER, Somme
}

On June 17, 1955 I went to Hudson Bay Junction to collect butterflies for the day. There are black spruce swamps to the north, east and west of the town, while to the south one finds jack pine with patches of poplar and willow. Thus Hudson Bay Junction has a large variety of plants, making it an ideal location for butterflies.

There had been showers on the afternoon and evening of June 16, and at nine o'clock next morning everything was very wet. The sky was overcast with the sun shining at iniervals through the clouds. Tine conditions did not seem too farorable for butterflies that morning. However, at ten o'clock when I was walking through the very wet grass and shrubbery of a clearing in the jack pine, I noticed a large Arctic Butterfly on a pea vine sunning itself. I had no trouble dropping my net over him, and I found that it was beautiful male Macoun's Arctic (Oeneis macounii). This is a beautiful insect with a two-inch wing expanse. The upper side of the wings is a bright orange, unmarked except for two eye-spots on the forewing and one on the hindwing Catching this Arctic made me glad that I had come, and I would have been satisfied if I hadn't caught another butterfly that day, as this was a new species for our collection.

As I continued through the jack pine I found that quite a few little blue butterflies were on the wing. I managed to collect four species of these. There were lots of Hoary Elfins (Incisalia polios) wherever bearberry was growing. The bush was full of Brown Elfins (Incisalia augustinus), and there were also many Pearl Crescents (Phyciodes tharos) and Tawny Crescents (Phyciodes batesii). Once the grass dried about noon, there was an abundance of butterflies everywhere.

About a mile south of Hudson Bay Junction there is a large clearing in the jack pines where the planes of the Department of Natural Resources land. The many flowers there made the clearing an excellent place for butterflies. I collected several Christina Sulphurs (Colias christina) and some Large Marbles (Euchloe ausenides). I found some Pine Elfins (Incisalia niphon) feeding on the blossoms of Meadow Parsnip. (Zizia). (It is interesting to note that this is an eastern species. It has been taken in Manitoba, but not in Alberta.) I collected a tattered American Painted Lady (Vanessa virginiensis). The condition of this butterfly suggested that it might have travelled some distance.

In the black spruce swamps there were large patches of Labrador Tea and Pale Laurel in blossom. These plants attract butterflies, and there were lots of Bog Fritillaries (Boloria eunomia) and some Jutta Arctics (Oeneis jutta).

About four o'clock in the afternoon I quit for the day, and counted my day's catch. I found that I had caught 27 species. This is an extraordinary catch for one day in Saskatchewan, where on an average day one collects 12 to 15 species. In the tropics where butterflies are more numerous than they are here, one might collect only 30 species in a day. A day's collecting in the Malay Islands will only produce 30 to 40 species, while in a day's collecting in Brazil one might take 40 to 70 species.

Saskatchewan has a good representation of butterflies - from 130 to 135 species. England has only 64 species, Germany 150. While there are only three species of Swallowtails (Papilio) in Europe, Saskatchewan has about six. We have three species of Swallow-tails in our collection, a collection that includes 84 Saskatchewan species in all.

EDITOR'S NOTE: A note from Ronald Hooper tells of a Mexican Sulphur collected by his brother near Somme in the summer of 1955. The butterfly was described as being in quite good condition in spite of the fact that it must. have windblown about 1,000 miles, as its nearest food plant is in the Central States. 